\title{
The Analyses of Auditors' Personal Characteristic and its Impact on the Public Accountants' Ethics
}

\author{
Amilin \\ Accounting Department \\ Faculty of Economic and Business \\ Syarif Hidayatullah State Islamic University Jakarta, Indonesia \\ E-mail: amilin@uinjkt.ac.id
}

\begin{abstract}
The aim of this study is to examine the differences in auditors personal characteristic and their impact on the implementation of the public accountants ethics. The respondents are the auditors who work in the public accounting firm in Jakarta, Indonesia. The sample selection using purposive sampling method. Methods of data collection using questionnaires. The method of hypothesis testing using ANOVA. The results of the study, first, there are differences in personal characteristics between public accountant who occupied positions at Senior Auditor, Manager, and Partner. A significant difference only in the senior auditor with a partner. There is a difference between the senior with the manager and the manager with the partner, but this difference is not significant. Second, the personal characteristics of a public accountant in the position of Senior Auditor, Manager and Partner does not significantly affect the application of ethics Public Accountant. This study is important because public accountants play a role as an actor in maintaining public confidence, especially in the financial statement audit.
\end{abstract}

Keywords-personal characteristic of public accountant, ethics of public accountant, senior auditor, manager, partner

\section{INTRODUCTION}

Studies about the effect of ethical values in decisionmaking has been recognized in the literature of social psychology and organizational behavior [1]; [2]. However, several studies in the field of business as well as the latest organization can not provide support for the results of studies on the influence of personal values to ethical decisions [3]; [4]. Research on ethical values in the accounting literature is still limited to the study of the value preference votes, but not related to the preference of ethical judgment and behavior [5]; [6].

Although few studies have been conducted to examine the feasibility of the code of conduct in ethical decision making by accountants, but none of them refers to whether a code of conduct actually significantly can influence the perception and considerations of ethical [7]. The effect of code of ethics to perception and considerations of ethical were first tested by [8].

Previous research in Indonesia about codes of conduct for accountant has been done by several researchers. The result of study by [9] indicate that there are significant differences in perceptions between groups of public accountants. While the results study by [10] show that there are differences in the perception of the importance of the code of ethics for accountants. The result study by [11] show that there are positive and significant effect on the perception and considerations of ethical for accountant regarding the code of ethics, personal ethical philosophy, and ethical corporate value.

Auditor unethical behavior can lead to financial scandals and business failures, loss of reputation and give rise to costs litigation [12]. The external auditors are most likely to blame when they failed to provide accurate information that can lead to financial and business failure [13].

Based on the Theory of Planned Behaviour (TPB), the auditor behavior determined by control of the attitudes and behavior as individual factors [14]. In addition, according to [15], the personal characteristics of auditors is a key driver in determining behavioral intention of auditor and the quality of their work. Although there are few studies about the quality of audits that focus on the relationship between individual characteristics and reduce audit quality behaviors. However, some of these studies do not examine differences in personal characteristics factors and their impact on the implementation of the code of ethics of public accountants. Therefore, this study aimed to analyze the average difference between the personal characteristics of public accountants and their impact on the implementation of the ethics of public accountants. This study is urgent to do because of the central role of public accounting as a spearhead in maintaining public confidence, especially in the financial statement audit.

\section{Literature REVIEW AND EMPIRICAL STUdIES}

\section{A. The Personal Characteristics}

Discussion about personal characteristics in organizational behavior includes people who entered the organization with certain characteristics that will affect their behavior in the workplace [16]. All individual attitudes and behavior shaped by personality and experience. Personal characteristic variables can affect the behavior of employees in terms of: perception, personal decision making, learning, and motivation in the form of biographical characteristics, abilities, values, attitudes, personality, and emotions [17]. Personal characteristics in this study consisted of three dimensions: professional skepticism, self-esteem and self-efficacy. 


\section{B. The Implementation of Public Accountants Ethics}

Ethics deals with statements about how people will behave toward others [18]. Ethics as a set of rules or norms or guidelines that govern human behavior, whether that should be done or should be abandoned embraced by a group or class of people or community or profession [19]. Application of public accountants ethics in this study using the dimensions of ethical awareness and concern for the ethical dimensions of the profession developed by [20] and [21] used in research.

\section{The Personal Characteristics and The Implementation of Public Accountants Ethics}

Study [22] examine the factors which degrade the quality auditors conduct audits (Reduced Audit Quality/RAQ). Results of study indicate that the auditor did not perform due to reduced audit quality that RAQ is unethical that can degrade the quality of the audit. Study of [23] show evidence that the reasons of auditor ethics influence towards the professional and ethical decision-making auditor.

Study of [24] showed evidence that the code of conduct was positive effect on the quality of judgment. Study of [25] indicates that there are ten factors that are considered by most accountants influence their attitudes and behavior. Suraida study of [26] showed empirical evidence that ethics, competence, experience audit and audit risk affect the accuracy of professional skepticism and giving opinions public accountant.

Based on a literature review, the results of previous studies, and structural framework, it can be formulated hypotheses as follows:

$\mathrm{H}_{\mathrm{a} 1}$ : There are differences in personal characteristics at the level careers among senior auditor, manager and partner.

$\mathrm{H}_{\mathrm{a} 2}$ : Personal characteristics of public accountants have an impact on the implementation of the ethics of public accountants.

\section{RESEARCH METHOD}

This study is a comparative study. Testing by comparing the personal characteristics among the 3 groups of respondents (senior auditors, managers, and partners). The population of is the external auditor who works in the Public Accountants Firms in Jakarta, Indonesia. The study period October to December 2015. Methods of sample selection using purposive sampling. Data were collected through questionnaires. The tool of analysis to test the hypothesis using Analysis of Variance (ANOVA).

Operationalization of Research Variables. Personal Characteristics Variable consists of three dimensions of these variables are: professional Skepticism, self-esteem and selfefficacy. Professional Skepticism using instruments [27]. Dimensional self-esteem using instruments [28]. Dimensional self-efficacy using instruments [29]. Respondents were measured with 5 Likert scale, from strongly disagree up to strongly agree. Variable Application of Ethics of Certified Public Accountants consists of two dimensions, there are: ethical awareness and concern for professional ethics. This variable was measured by instruments of [30] and [31]. Respondents were measured with 5 Likert scale, from strongly disagree up to strongly agree.

\section{FINDINGS AND DISCUSSION}

\section{A. Findings}

Table I presents the data about the profile of respondents based on their position in the Public Accountants Firms.

TABLE I. DESCRIPTION OF THE POSITION OF RESPONDENTS IN CPA FIRMS

\begin{tabular}{|l|c|c|c|c|}
\hline \multicolumn{1}{|c|}{ Position } & Frequency & Percent & $\begin{array}{c}\text { Valid } \\
\text { Percent }\end{array}$ & $\begin{array}{c}\text { Cumulative } \\
\text { Percent }\end{array}$ \\
\hline Senior & 30 & 33.3 & 33.3 & 33.3 \\
\hline Manager & 30 & 33.3 & 33.3 & 66.7 \\
\hline Partner & 30 & 33.3 & 33.3 & 100.0 \\
\hline Total & 90 & 100.0 & 100.0 & \\
\hline
\end{tabular}

Sources: Primary data are processed

From Table I, it can be seen that the number of auditors who occupies a position as a senior auditor as many as 30 people $(33.3 \%)$, manager of the auditor as many as 30 people $(30.3 \%)$, and partner auditors as many as 30 people $(30.3 \%)$. Thus, the overall total respondents who participated in this study amounted to 90 people.

The following are the output of levene's test. Anova assumptions can be met if the data have the same variance.

TABLE II LEVENE'S TEST OF EQUALITY OF ERROR VARIANCES

Dependent Variable: CHARACTER

\begin{tabular}{|r|r|r|r|}
\hline \multicolumn{1}{|c|}{ F } & df1 & df2 & Sig. \\
\hline 2.348 & & 2 & \\
\hline
\end{tabular}

Tests the null hypothesis that the error variance of the dependent variable is equal across groups.

a. Design: Intercept + POSITION

Sources: Primary data are process

The result of Lavene's test in Table II show that the calculated $F$ value of 2.345 . This value is not statistically significant because of sig $=0.102$, so the variances in the distribution of the data are the same. Thus, these models meet the assumptions of ANOVA, so that it can proceed to the next test. The following are the results of the Test of BetweenSubject Effects as an additional analysis. 
TABEL III. TESTS OF BETWEEN-SUBJECTS EFFECTS

Dependent Variable: Personal Characteristic

\begin{tabular}{|l|r|r|r|r|r|}
\hline \multicolumn{1}{|c|}{ Source } & \multicolumn{1}{c|}{$\begin{array}{c}\text { Type III } \\
\text { Sum of } \\
\text { Squares }\end{array}$} & \multicolumn{1}{c|}{ df } & \multicolumn{1}{c|}{$\begin{array}{c}\text { Mean } \\
\text { Square }\end{array}$} & \multicolumn{1}{c|}{ F } & Sig. \\
\hline $\begin{array}{l}\text { Corrected } \\
\text { Model }\end{array}$ & $462.467^{\mathrm{a}}$ & 2 & 231.233 & 3.480 & .035 \\
\hline Intercept & 596336.400 & 1 & 596336.400 & 8974.238 & .000 \\
\hline POSISI & 462.467 & 2 & 231.233 & 3.480 & .035 \\
\hline Error & 5781.133 & 87 & 66.450 & & \\
\hline Total & 602580.000 & 90 & & & \\
\hline $\begin{array}{l}\text { Corrected } \\
\text { Total }\end{array}$ & 6243.600 & 89 & & & \\
\hline
\end{tabular}

a. R Squared $=.074$ (Adjusted R Squared $=.053$ )

Sources: Primary data are processed

The results of Test of Between-Subject Effect on Table III show that calculated $F$ value of 8947.238 to intercept and significant at 95\% confidence level (alpha 5\%). Likewise the variable position with calculated $\mathrm{F}$ value of 3.480 and significant at 95\% confidence level (alpha 5\%). It can be concluded that the position of Auditor in Public Accountants Firm (Senior Auditor, Manager and Partner) can affect the personal characteristics of Certified Public Accountants (CPA). In other words, there is a difference between the character of a public accountant who occupied positions at the Senior Auditor, Manager and Partner, so the first hypothesis (Ha1) supported.

For a more detailed, look at the magnitude of the difference between the personal characteristics of a public accountant who occupied positions as Senior Auditor, Manager and Partner can be seen in the output Tukey test and test Benferoni in Table IV below.

\section{TABLE IV. OUTPUT OF RESULTS OF TUKEY TEST AND BONFERRONI TEST}

Multiple Comparisons

Dependent Variable: Personal Characteristic

\begin{tabular}{|c|c|c|c|c|c|c|c|}
\hline & \multirow[b]{2}{*}{$\begin{array}{c}\text { (I) } \\
\text { POSITION }\end{array}$} & \multirow[b]{2}{*}{$\begin{array}{c}(\mathrm{J}) \\
\text { POSITION }\end{array}$} & \multirow{2}{*}{$\begin{array}{c}\text { Mean } \\
\text { Differe } \\
\text { nce (I- } \\
\text { J) }\end{array}$} & \multirow[b]{2}{*}{\begin{tabular}{|l|} 
Std. \\
Error
\end{tabular}} & \multirow[b]{2}{*}{ Sig. } & \multicolumn{2}{|c|}{$\begin{array}{c}\text { 95\% Confidence } \\
\text { Interval }\end{array}$} \\
\hline & & & & & & $\begin{array}{l}\text { Lower } \\
\text { Bound }\end{array}$ & $\begin{array}{l}\text { Upper } \\
\text { Bound }\end{array}$ \\
\hline \multirow{6}{*}{$\begin{array}{l}\text { Tukey } \\
\text { HSD }\end{array}$} & \multirow[t]{2}{*}{ Senior } & Manager & -3.17 & 2.105 & .294 & -8.19 & 1.85 \\
\hline & & Partner & $-5.53^{*}$ & 2.105 & .027 & -10.55 & -.51 \\
\hline & \multirow[t]{2}{*}{ Manager } & Senior & 3.17 & 2.105 & .294 & -1.85 & 8.19 \\
\hline & & Partner & -2.37 & 2.105 & .502 & -7.39 & 2.65 \\
\hline & \multirow[t]{2}{*}{ Partner } & Senior & $5.53^{*}$ & 2.105 & .027 & .51 & 10.55 \\
\hline & & Manager & 2.37 & 2.105 & .502 & -2.65 & 7.39 \\
\hline \multirow{6}{*}{$\begin{array}{l}\text { Bonferro } \\
\text { ni }\end{array}$} & \multirow[t]{2}{*}{ Senior } & Manager & -3.17 & 2.105 & .408 & -8.30 & 1.97 \\
\hline & & Partner & $-5.53^{*}$ & 2.105 & .030 & -10.67 & -.40 \\
\hline & \multirow[t]{2}{*}{ Manager } & Senior & 3.17 & 2.105 & .408 & -1.97 & 8.30 \\
\hline & & Partner & -2.37 & 2.105 & .792 & -7.50 & 2.77 \\
\hline & \multirow[t]{2}{*}{ Partner } & Senior & $5.53^{*}$ & 2.105 & .030 & .40 & 10.67 \\
\hline & & Manager & 2.37 & 2.105 & .792 & -2.77 & 7.50 \\
\hline
\end{tabular}

Based on observed means.

The error term is Mean Square (Error) $=66.450$.

*. The mean difference is significant at the .05 level.

Sources: Primary data are processed

TABle V. The ImPaCt OF Personal Characteristics ON IMPlementation of PUblic ACCOUNTANTS ETHICS

Test of Between-Subjects Effect

Dependent Variable: ETHICS

\begin{tabular}{|l|r|r|r|r|r|}
\hline \multicolumn{1}{|c|}{ Source } & $\begin{array}{c}\text { Type III Sum } \\
\text { of Squares }\end{array}$ & \multicolumn{1}{c|}{ df } & $\begin{array}{c}\text { Mean } \\
\text { Square }\end{array}$ & \multicolumn{1}{c|}{ F } & \multicolumn{1}{c|}{ Sig. } \\
\hline Corrected Model & $1339.313^{\mathrm{a}}$ & 27 & 49.604 & 1.652 & .053 \\
\hline Intercept & 127090.517 & 1 & 127090.517 & 4233.649 & .000 \\
\hline CHARACTERS & 1339.313 & 27 & 49.604 & 1.652 & .053 \\
\hline Error & 1861.187 & 62 & 30.019 & & \\
\hline Total & 235763.000 & 90 & & & \\
\hline Corrected Total & 3200.500 & 89 & & & \\
\hline
\end{tabular}

Dependent R Squared $=.418$ Variable

a. R Squared $=.418$ (Adjusted R Squared $=.165$ )

Sources: Primary data are processed

The results of Tukey Test and Benferoni Test as presented in Table IV above show that there are differences in personal characteristics between the auditor Senior Auditor and Manager with an average value of 3.17 and the difference was not statistically significant difference with the value of $\mathrm{p}=$ 0.294. Differences in personal characteristics between senior auditor and partner with the average value of a difference of 5.53 and this difference statistically significant with $\mathrm{p}=0.027$. While the differences in personal characteristics between the manager and partner with the average value of a difference of 2.37 and is statistically the difference is insignificant with $\mathrm{p}=$ 0.502 .

Table V presents the result of second hypothesis test $\left(\mathrm{H}_{\mathrm{a} 2}\right)$. This table describe the impact of personal characteristics differences on the implementation of the ethics of public accountants.

From Table V, the results of the Test of Between-Subject Effects can be seen that the calculated $F$ value of $127,090.517$ to intercept and not significant at the $95 \%$ confidence level (alpha 5\%). Therefore variable Personal Characteristics of auditor effect is not significant to the variable application of the public accountants ethics. It can be concluded that the differences in personal characteristics of a public accountant in the position of Senior Auditor, Manager and Partner does not affect the application of Public Accountant ethics. Thus, the research hypothesis which states that the differences in personal characteristics affect the application of the ethics of auditors of public accountants cannot be supported.

\section{B. Discussion}

From the results of testing can be concluded that personal characteristics have significant difference only in the position of senior auditor with a partner, whereas among the senior auditor with the manager and the manager with a partner there is have a difference, but it was not significant. This finding implies that the significantly differences on personal 
characteristics between senior auditor with a partner showed that the age and experience of the auditor will shape the character of an auditor to a more mature. Maturity is expected to have a positive impact on the performance and quality of the audit. The more experienced and age an auditor should they have the character more thoughtful, more independent. In addition, they should have the awareness to implement the code of ethics of public accountants.

Previous results of studies have not been a lot of research about differences in personal characteristics on a public accountant at different levels. However, at least the findings of this study are relevant to the results of study conducted by [32], which examines the impact of the auditors behavior on audit quality (reduced audit quality / RAQ). In addition, this study also consistent with the results of study conducted by [33] which showed empirical evidence that the orientation and ethical reasons of auditor influence on professional and ethical decision-making of public accountant.

Results of Test of Between-Subject Effect on second hypothesis testing (Ha2) showed that the differences of personal characteristics in a public accountant on the position of Senior Auditor, Manager and Partner can not affect the application of Public Accountant ethics. In other words, the research hypothesis which states that the differences of personal characteristics affect the application of public accountants ethics can not be supported. This finding implies that the application of public accountants ethics by auditor at the level of senior auditor, manager, and as well as at the partner level are not solely influenced by personal characteristics auditor. Thus, auditors at any level characters have the same tendency toward consciousness in implementing the code of ethics of public accountants. Not influential the personal characteristics variables on the application of the public accountants ethics may be due to differences between the levels of public accountants that are not significant.

The results of previous studies that examined the impact of differences in personal characteristics on the application of the code of ethics of public accountants has not been done. However, at least the findings of this study are relevant to the results of study [34] found empirical evidence that the existence of a code of ethics positively effect on the quality of judgment. That is, the code of ethics of public accountants will be more useful when applied to people who have more experience so can ber improve the quality of audit judgment.

Other study which relevant to this finding is [35] showed empirical evidence that factors: religiosity, education, organizational, emotional quotient, family environment, life experiences, remuneration, legal, position or status effect to the application of the public accountants ethics. While study [36] showed that empirical evidence that ethics, competence, experience audit and audit risk effect to professional skepticism.

The findings of this study, does not have a significant impact on the application of public accountant ethics, but it is expected to be a concern for practitioners of audit, academics, regulators and users of audit services about the importance of applying of public accountants ethics. If the code of ethics of public accountants consistently applied by the auditor, it is expected to violations that occurred were conducted by public accountants can be minimized. For academics, at least get an idea of the importance to understanding the public accountants ethics can be transferred to the students. For the regulators, both the Institute of Indonesia Certified Public Accountants, the Ministry of Finance on Directorate General of Financial Professions Development Center, Financial Services Authority (FSA), as well as other relevant regulators in making rules and policies related to public accounting profession. For users of public accounting firm, should be able to determine the critical choice in selecting services of public accountants that has a reputation for keeping a commitment in the implementation of the code of public accountants ethics.

\section{Conclusion And Suggestions}

The results of this study have two conclusions: First, there are differences in personal characteristics between public accountant who occupied positions at the Senior Auditor, Manager and Partner. Differences in personal characteristics are significant only in the position of senior auditor with a partner, whereas among the senior auditor with the manager and the manager with a partner there is have a difference, but the differentiation was not significant. Second, the personal characteristics of a public accountant in the position of Senior Auditor, Manager and Partner does not significantly affect the application of Public Accountant ethics.

This study has limitations as follows: First, the purpose of study in the behavioral accounting field generally to predict and to explain the behavioral phenomena that may occur, but in fact, the behavior problem is not easy to predict because it has a high level uncertainty. Second, the results of study showed that differences in personal characteristics are significant only on the auditor senior with a partner, while at another level does not prove to be significantly different. These findings do not reveal to a junior auditor level. Third, the area of study is only done in the area of around the Jakarta city, so generalizing these results is not describe all of Indonesia.

Recommendation for further study are as follows: First, replacing the application of public accountants ethics variable with other variables, for example: variable of independent public accountants, audit quality, professional commitment, or other variables which relevant to the context of the study. Secondly, adding that the auditor career at junior level, so the possibility of a personal characteristic differences between the levels of public accountants to be more open. Third, expanding the survey area, so that results of study are more likely to be generalized.

\section{REFERENCES}

[1] M. Rokeach. The Nature of Human Vakues, New York: The Free Press, 1973.

[2] S. D. Hunt and S. A. Vitell. General Theory of Marketing Ethics. Journal of Macromarketing, 6 (Spring), 5-16, 1986.

[3] I. P. Akaah. The Influence of Non-Anonymity Deriving From Feedback of Research Results on Marketing Professionals' Research Ethics Judgements. Journal of Business Ethics 9 (12):949 - 959, 1990. 
[4] J. E. Finegan. The impact of personal values on judgments of ethical behaviour in the workplace. Journal of Business Ethics , 13, 747-755, 1994.

[5] T.E. Wilson Jr., S. Pinac-Ward, \& D. R. Ward. CPA values analysis: Towards a better understanding of the motivations and ethical attitudes of the profession. In L. A. Ponemon (Ed). Research on Accounting Ethics 4, 201-210, Greenwich, CT: JAI Press, 1998.

[6] D. E. Giacomino and M. D. Akers. An Examination of the Differences Between Personal Values and Value Types of Female and Male Accounting and Nonaccounting Majors, Issues in Accounting Education, (13), pp. 565-584, 1998.

[7] A. Wibowo. The Effect of Accountants Code of Ethics, Personal Ethical Philosophy, Corporate Ethical Value Of Perception Ethical and Ethical Considerations Auditor (Empirical Study on Public Accounting Firms in Jakarta). Serat Acitya- Scientific Journals, UNTAG Semarang, 2014.

[8] D. E. Ziegenfuss and O. B. Martinson. "Looking at what influences ethical perception and judgment", Management Accounting Quarterly, Fall, pp. 41-47, 2000.

[9] R. Desriani, Perception of Accountaants about Indonesia Code of Ethics. Unpublised Reserch Report. Post-Graduate. Gadjah Mada University. Yogyakarta, 1993.

[10] Sihwahjoeni \& M. Goedono. Perception of Accountant About Code of Ethics of Accountant. Journal Riset Akuntansi Indonesia. Vol 3, No. 2, Juli: 168-184, 2000.

[11] A. Wibowo. The Effect of Accountants Code of Ethics, Personal Ethical Philosophy, Corporate Ethical Value Of Perception Ethical and Ethical Considerations Auditor (Empirical Study on Public Accounting Firms in Jakarta). Serat Acitya- Scientific Journals, UNTAG Semarang, 2014.

[12] J. T. Morris. The Impact of Authentic Leadership and Ethical Organizational Culture on Auditor Behavior," Ph.D. dissertation, University of San Diego, U.S.A, 2009.

[13] M. N. M. Nor. "Auditor Stress: Antecedents and Relationships to Audit Quality," Ph.D Dissertation, Edith Cowan University, Australia, 2001.

[14] I. Ajzen. "The theory of planned behavior," Organizational Behavior and Human Decision Processes, vol. 50, pp. 179-211, 1991.

[15] Financial Reporting Council. Challenges for Audit Committees Arising from Current Wconomic Condition. Acceses from https://www.ifac.org/system/files/meetings/files/3769.pdf, 2008.

[16] R. Stephen P. Organizational Behavior. Eleventh Edition. New Jersey: Prentice Hall Inc. 2005.

[17] R. Kreitner and A. Kinicki. Organizational Behavior. Fifth Edition. The Mc Graw-Hill Companies, Inc. 2001.

[18] Kell, W.G., W.C. Boynton and R.N. Johnson. Modern Auditing. Edition 7th, John Wiley \& Sons Inc 2006.

[19] Maryani dan U. Ludigdo. 2001. Survey on Factors Influencing Ethical Attitudes and Behavior Accountant. Journal of TEMA. Vol. II, No. 1, Maret; 49-62, 2001.

[20] Cohen, Elliot D and Michael Davis. Ethics and the Legal Profession, 2nd Edition, forthcoming Prometheus Books. 1997.

[21] I. Suraida. Influence of Ethics, Competence, experience, Audit Risk and Auditor Professional Skepticism Toward Giving Opinion Accuracy Public Accountant (Survay against public accountants in Indonesia).
Disertation. Bandung: Graduate Program Padjadjaran Univetsity (Unpublished). 2003.

[22] C.F. Malone and F. Roberts. Factors Associated with The Incidence of Reduced Audit Quality Behaviors. Auditing. Sarasota: Vol. 15, Iss. 2; pg. 49, 16 pgs, 1996.

[23] Lawrence \& Shaub, M. The Ethical Construction of Auditors: An Examination of The Effect of Gender and Career Level. Managerial Finance, Vol. 23, No. 12, pp. 3-21, 1997.

[24] G. Pflugrath, N.M. Bennie and L. Chen. The impact of codes of ethics and experience on auditor judgments. Managerial Auditing Journal, Vol. 22 No. 6, pp. 566-589, 2007.

[25] Maryani dan U. Ludigdo. 2001. Survey on Factors Influencing Ethical Attitudes and Behavior Accountant. Journal of TEMA. Vol. II, No. 1, Maret; 49-62, 2001.

[26] I. Suraida. Influence of Ethics, Competence, experience, Audit Risk and Auditor Professional Skepticism Toward Giving Opinion Accuracy Public Accountant (Survay against public accountants in Indonesia). Disertation. Bandung: Graduate Program Padjadjaran Univetsity (Unpublished). 2003.

[27] Hurt, K., Eining, M. \& Plumlee, D. Professional scepticism: A model with implications for research, practice, and education. Working paper, University of Wisconsin., 2003.

[28] Rosenberg, M. Society and The Adolescent Selflimage. Princeton, NJ: Princeton University Press., 1965.

[29] Jones, G. Socializatin Tactics, Self-Efficacy, and New Comers, Adjustment in Organization. Academy Management Journal, 19 Juny 1986.

[30] Cohen, Elliot D and Michael Davis. Ethics and the Legal Profession, 2nd Edition, forthcoming Prometheus Books. 1997.

[31] I. Suraida. Influence of Ethics, Competence, experience, Audit Risk and Auditor Professional Skepticism Toward Giving Opinion Accuracy Public Accountant (Survay against public accountants in Indonesia). Disertation. Bandung: Graduate Program Padjadjaran Univetsity (Unpublished). 2003.

[32] C.F. Malone and F. Roberts. Factors Associated with The Incidence of Reduced Audit Quality Behaviors. Auditing. Sarasota: Vol. 15, Iss. 2; pg. 49, 16 pgs, 1996.

[33] Lawrence \& Shaub, M. The Ethical Construction of Auditors: An Examination of The Effect of Gender and Career Level. Managerial Finance, Vol. 23, No. 12, pp. 3-21, 1997.

[34] G. Pflugrath, N.M. Bennie and L. Chen. The impact of codes of ethics and experience on auditor judgments. Managerial Auditing Journal, Vol. 22 No. 6, pp. 566-589, 2007.

[35] Maryani dan U. Ludigdo. 2001. Survey on Factors Influencing Ethical Attitudes and Behavior Accountant. Journal of TEMA. Vol. II, No. 1, Maret; 49-62, 2001.

[36] I. Suraida. Influence of Ethics, Competence, experience, Audit Risk and Auditor Professional Skepticism Toward Giving Opinion Accuracy Public Accountant (Survay against public accountants in Indonesia). Disertation. Bandung: Graduate Program Padjadjaran Univetsity (Unpublished). 2003. 